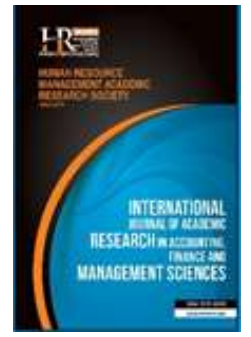

International Journal of Academic Research in Accounting, Finance and Management Sciences

Vol. 10, No.2, April 2020, pp. 76-86

E-ISSN: 2225-8329, P-ISSN: 2308-0337

(c) 2020 HRMARS

www.hrmars.com

To cite this article: Julkid, N. F. B., Lau, W.-T. (2020). Capital Structure Decision: Micro- and Macroeconomic Determinants in Malaysia, International Journal of Academic Research in Accounting, Finance and Management Sciences 10 (2):76-86.

\title{
Capital Structure Decision: Micro- and Macroeconomic Determinants in Malaysia
}

\author{
Noor Farahanim Binti Julkid ${ }^{1}$, Wei-Theng Lau ${ }^{2}$ \\ ${ }^{1,2}$ School of Economics and Management, Universiti Putra Malaysia, 43400 Seri Kembangan, Selangor, Malaysia \\ ${ }^{1}$ E-mail: farahanim1806@gmail.com, ${ }^{2} E$-mail: Iwtheng@upm.edu.my (Corresponding author)
}

\begin{abstract}
This paper attempts to analyse the determinants of capital structure decisions among Malaysian firms by considering both the firm-specific (micro-economic) and the macro-economic factors. Using a sample covering 612 listed firms across major business sectors in the Bursa Malaysia during a span of ten recent years (2009-2018), the analysis proposes that both the micro- and macro-economic determinants are relevant for decision makers in understanding the financial leverage of firms. Panel data regressions suggest a significant positive relationship of non-debt tax shield, firm size, tangibility, interest rate and stock market development with debt ratio of firms. Meanwhile, a significant negative relationship is found for profitability, liquidity and gross domestic product. While the macro-economic variables are proposed to be fundamentally important in this study, they do not affect the roles of commonly proposed firm-specific factors implied by the existing capital structure theories. The results are also robust across the estimations with pooled ordinary least squares, fixed effects and random effects models. This paper particularly focuses on providing empirical evidence from the Malaysian market, extendable to cover the other countries for future investigations.

Key words Capital Structure, Macroeconomic, Microeconomic, Bursa Malaysia, Panel Data Analysis.

Received: 07 May $2020 \quad$ c) The Authors 2020

Revised: 10 Jun 2020 Published by Human Resource Management Academic Research Society (www.hrmars.com)

Accepted: 25 Jun 2020 This article is published under the Creative Commons Attribution (CC BY 4.0) license. Anyone may Published Online: $06 \mathrm{Jul} 2020$ reproduce, distribute, translate and create derivative works of this article (for both commercial and non-commercial purposes), subject to full attribution to the original publication and authors. The full terms of this license may be seen at: http://creativecommons.org/licences/by/4.0/legalcode
\end{abstract}

\section{Introduction and literature review}

Capital structure is how firms finance their operations by using a combination of debt and equity. Financial leverage can be measured by debt ratio, debt-equity ratio, debt-capital ratio and so on. High leverage may imply risky financial position while low leverage indicates conservativeness in fund-raising exercises. Many have suggested having an optimal capital structure which balances the use of internal and external funds in the effort of maximising firm value (Salam \& Shourkashti, 2019). Capital structure can also be used as an indicator by potential shareowners and creditors for their investment decision makings. Factors contributing to capital structure decisions have been widely studied, especially pertaining to firmspecific factors (Baharuddin et al., 2011; Mahmood \& Dollah, 2011; Pepur et al., 2016; Vo, 2017). This paper aims to supplement the current literature by incorporating possible macroeconomic factors on capital structure decision, particularly of businesses in Malaysia. Besides internal factors like size, asset tangibility, taxation, profitability and liquidity of firms, external economic factors could be important in influencing the determination of capital structure (Mokhova \& Zinecker, 2014). Some researchers find that in times of good economic condition, firms change their capital structure more promptly compared with economic downturns (Tomschik, 2015). This paper aims to look into the considerations of both. 
The current literature of capital structure is usually justified by several renowned theories. Modigliani and Miller proposed the first capital structure theory in 1958, arguing that the market value of firms does not correlate with capital structure. Its perfect market assumptions do not consider some important factors that usually affect firm value such as flotation cost, corporate tax, transaction cost and bankruptcy cost. In the 1963's paper later, they propose the tax benefit on firm value because the interest paid on borrowed funds is tax deductible. This interest tax shield reduces the real cost of debt and increases firm value. Agency theory is based on which managers have better information about firm's growth and prospects as compared with the general market participants, suggesting a potential asymmetric information problem (Pepur et al., 2016). This theory implies using internal funds first to finance business activities because information asymmetry could make the cost of external borrowing high (Tehrani \& Khoee, 2017). This is in line with the pecking order theory, which prioritises internal financing. In the context of corporate governance, shareholders act as the principal and authorises managers as their agents to make decisions consistent with shareholders' interest. Potential conflicts of interest between the two parties may exist though. For example, managers may turn to internal financing and avoid dividend payments. Jensen and Meckling (1976) argue that firms have to reduce agency cost in order to achieve an optimal capital structure. The optimal capital structure proposition is consistent with the trade-off theory which suggests balancing the benefits and costs of sourcing debt funding (Kraus \& Litzenberger, 1973).

The trade-off theory implies that profitability has a positive relationship with leverage. Tax deductibility of interest expenses should encourage firms to use more debt financing. Besides, firms earning high profits have a better capability to serve debt obligations, thus increasing the chances of debt financing (Pepur et al., 2016; Daskalakis et al., 2017; Huong, 2017). On the other hand, pecking order theory suggests the opposite. Profitable firms have ample internal funds generated to finance their business and growth. Therefore, there would be a negative relationship between profitability and leverage (Bokpin, 2009; Baharuddin et al., 2011; Joeveer, 2013; Batthacharjee \& Dash, 2015; Memon et al., 2015; Nejad \& Wasiuzzaman, 2015; Temimi et al., 2016; Ying et al., 2016; Vo, 2017; Alqatamin, 2018; Khemiri \& Noubbigh, 2018; Kiraci \& Aydin, 2018).

Besides, the trade-off theory also implies that large firms tend to use more debt financing due to the lower likelihood of bankruptcy (Baharuddin et al., 2011; Hamousek \& Ashamsur, 2011; Joeveer, 2013; Memon et al., 2015; Nejad \& Wasiuzzaman, 2015; Temimi et al., 2016; Ying et al., 2016; Khemiri \& Noubbigh, 2018; Kiraci \& Aydin, 2018). However, some claim to find the opposite (Joeveer, 2013; Bandyopadhyay \& Barua, 2016; Ramli et al., 2019). The pecking order theory proposes that large firms have a low information asymmetry problem in the capital market, and so they get easier and cheaper access to external funding compared to small firms, suggesting a negative relationship between firm size and financial leverage (Pepur et al., 2016). Pertaining to assets tangibility, the trade-off theory also implies a positive association with leverage. Baharuddin et al. (2011) agree that assets tangibility is positively related to total debt when firms have high tangible assets. Khemiri \& Noubbigh (2018) suggest that the positive relationship could be due to the confidence of repayment by creditors. The pecking order theory, on the other hand, suggests a negative relationship between tangibility and leverage. Pepur et al. (2016) find a negative but statistically insignificant coefficient of tangibility and argue that tangible assets do not necessarily help as a collateral during financial distress. Temimi et al. (2016) reveal a negative relationship for countries that do not enforce taxes. Nejad \& Wasiuzzaman (2015) and Huong (2017) also suggest that there is no significant relationship between tangible assets and leverage.

Non-debt tax shield (NDTS) may help to explain the borrowing behaviour of firms in taking advantages of tax benefit. Ying et al. (2016) find a significant negative relationship for consumer firms. Firms may opt for a lower level of borrowing if the NDTS is already high (Pepur et al., 2016; Daskalis et al., 2017; Kiraci \& Aydin, 2018). Nejad \& Wasiuzzaman, (2015) also find the relationship to be negative, but significant only at the firm levels and insignificant at industry and country levels, which is possibly due to the impacts from the other attributes. However, Battacharjee \& Dash (2015) find a positive relationship and explain that firms may use as much debt as possible to maximise firm value. According to the pecking order theory, firms having high liquidity position tend to use internal funds instead of external financing, suggesting a negative relationship between financial liquidity and leverage. This is in line with the results found by Nejad \& Wasiuzzaman (2015), Ying et al., (2016), and Kiraci \& Aydin (2018). Pepur et al. (2016) 
and Huong (2017) explain that the relationship is positive because a better liquidity reduces the possibility of economic failure and lowers the potential costs of bankruptcy with sufficient amounts of short-term assets in covering outstanding liabilities. Healthier firm's liquidity position would increase its borrowing capacity. Rahman (2016) finds that corporate tax is positively significant related to economic leverage which indicates that firms may prefer tax shield and the similar observation is found by Joeveer (2013), Memon et al. (2015) and Tomschik (2015). In contradict Mokhova \& Zinecker (2014), Huong (2017) and Khemiri \& Noubbigh (2018) find a negative relationship, suggesting that taxation may not be the main consideration in raising external capital.

Apart from the commonly tested firm characteristics, this paper aims to include a few external factors that may rationally influence capital structure decisions, which include gross domestic product (GDP), inflation, interest rate, and stock market development. According to the trade-off theory, it is expected to observe a positive relationship between GDP and leverage due to high profitability during economic booms. This is consistent with the findings by Bokpin (2009), Joeveer (2013), Temimi et al. (2016), Memon et al. (2015), Rehman (2016) and Huong (2017). In contrary, the pecking order theory implies a negative relationship between GDP and debt financing. For example, Khemiri \& Noubbigh (2018) find such a negative relationship in five countries in the Sub-Saharan Africa due to increasing growth opportunities during economic booms. It is also consistent with the findings by Gajurel (2006), Bokpin (2009), Muthama et al. (2013), Joeveer (2013), Mokhova \& Zinecker (2014), Nejad \& Wasiuzzaman (2011) and Pepur et al. (2016). It suggests that increase in economic activities may reduce the need for leverage.

Inflation and leverage could have an unclear relationship. Temimi (2016) proposes a positive relationship for the GCC countries, Malaysia and Thailand and claims a lower real cost of debt during inflationary periods. Besides, firms may favour tax savings during inflationary (Nejad \& Wasiuzzaman, 2015). Gajurel (2006) suggests that during inflationary, short-run interest rates increase faster than the long run. The cost of debt would be more expensive for the short run and so firms would prefer to increase the long-term debt. Such positive finding is also supported by Muthama et al. (2013), Memon et al. (2015), Nejad \& Wasiuzzaman (2015), Pepur et al. (2016) and Huong (2017). On other hand, Tehrani \& Khoee (2017) demonstrate that during inflationary firms get to be riskier due to volatility of revenue and costs and so may avoid to increase their debt further. This negative relationship is also found by Gajurel (2006), Bokpin (2009), Muthama et al. (2013), Memon et al. (2015), and Ying et al. (2016). Rehman (2016) argues that in some cases like during the currency depreciation in Pakistan, the increasing amount of purchases would increase the sales of businesses. However, such devaluation also increases inflation that leads to cost escalations and thus firms are not able to take advantage to borrow more. Some mixed findings are also found. For example, Mokhova \& Zinecker (2014) investigate the effects of macroeconomic factors in the European countries from 2006 to 2010 and find that inflation and capital structure has a positive relationship in France and Greece but negative in the Czech Republic, Slovakia, Poland, Hungary and Germany.

Rationally, firms tend to use a high amount of leverage when the interest rate is low due to low cost of debt financing. On the contrary, higher level of interest rate would result an increase in the cost of opportunity. Firms should hold their cash and this tend to cause to the substitution effect between financing securities. Hence, firms would desire equity financing during high interest rate times. Besides, an increase in the interest rate would result in a higher possibility of financial distress. Mokhova \& Zinecker (2014) find a negative relationship between interest rate and leverage measured in both the short-term and long-term debt. Memon et al. (2015) and Nejad \& Wasiuzzaman (2015) also agree that low interest rates lead firms to issue more debt. Rehman (2016) find that interest rate in Pakistan is comparatively high thus the cost of financial distress is more than the tax benefits of using debt. Nevertheless, Khemiri \& Noubbigh (2018) suggest that firms tend to increase debt when the nominal interest rate increases, accompanied by the expected increase in inflation. Firms would increase debt now compared to later. Bokpin (2009) finds firms will increase short-term debt first compared to the long term. Meanwhile, Muthama et al. (2013) claim that interest rates have a positive relationship with long-term debt but a negative relationship with short-term debt.

Stock market is generally perceived to help in revealing financial health and value of firms through their share prices. This is as to why stock market development could play an important role in deciding the 
capital structure of firms. Firms are able to raise more funds if they issue equity to finance their business when the stock market is good. Issuing equity at a higher price also implies a lower cost of equity. Agarwal \& Mohtadi (2004) suggest that stock market can be speculative to public, thus small or medium firms would favour small debt in the long run. The negative relationship is consistent with the claims by Bokpin (2009), Muthama et al. (2013), Khemiri \& Noubbigh (2018), and Temimi et al. (2018). Nevertheless, Gajurel (2006), Tomschik (2015), Rehman (2016) and Tai (2017) propose a positive relationship between stock market development and leverage. In some markets, the development is still at the early stage so firms may acquire more debt instead of issuing equity (Rehman, 2016). Besides, good stock market performance causes firms use more leverage as it indicates a good condition for stock prices and makes the lenders more willingly to offer funds to these firms. Tai (2017) argues that firms use more debt could be due to the decrease in lending rate as a result of diversification of external sources from stock market, driving a lower cost of borrowing.

Fundamentally, macroeconomic factors are perceived to be important to firm-level financial decisions. If firms are well aware of economic conditions like high inflation or good stock market performance, they would be able to make better capital structure decisions to maximise firm value. Problems like over leverage may be avoided. In addition, this paper focuses on the analysis covering observations in Malaysia for the years spanning from 2009 to 2018 to serve as an updated study about capital structure behaviours in this renown emerging market. The firm-specific determinants of capital structure that we consider are NDTS, size, tangibility, taxation, profitability and liquidity. The macroeconomic factors i.e. GDP, inflation, interest rate and stock market development are also covered in the analysis. To the best of our knowledge, there are still limited updated studies comparing the roles of both micro- and macroeconomic factors across major business sectors in Malaysia. The variable measurements and descriptions, model specifications and data sources will be discussed in the next section. Section 3 discusses the results whereas the final section concludes with a summary of findings and related implications.

\section{Methodology of research}

This section discusses the data and methodology adopted to achieve the research objectives. The analysis is to investigate the micro- and macroeconomic factors on capital structure of active firms listed on the Bursa Malaysia between years 2009 and 2018. All listed firms in the Bursa Malaysia are included except for the finance-related firms which include banks, equity investment instruments, financial services, insurance, non-equity investment instruments and real estate investment trusts. Consequently, a total of 612 firms from 34 sub sectors are covered in this study. The list of these sectors is as follows: Aerospace \& Defence, Alternative Energy, Automobile \& Parts, Beverages, Chemicals, Construction \& Materials, Electricity, Electronic \& Electrical Equipment, Fixed Line Telecommunications, Food \& Drug Retailers, Food Producers, Forestry \& Paper, Gas, Water \& Multi-utilities, General Industrials, General Retailers, Health Care Equipment and Services, Household Goods \& Home Construction, Industrial Engineering, Industrial Metals \& Mining, Industrial Transportation, Leisure Goods, Media, Mining, Oil \& Gas Producers, Oil Equipment \& Services, Personal Goods, Pharmaceuticals \& Biotechnology, Real Estate Investment \& Services, Software and Computer Services, Support Services, Technology Hardware \& Equipment, Tobacco, Travel \& Leisure and Unclassified sector.

The variables to be tested in this study are largely supported by the existing literature. The required data for variable computations are sourced from Thomson Reuters Datastream, World Development Indicators and Department of Statistics Malaysia. Based on the current literature, a few measurements are accepted to proxy firm's financial leverage. They include the overall leverage (Baharuddin et al., 2011; Muthama et al., 2013; Nejad \& Wasiuzzaman, 2015; Memon et al., 2015; Temimi et al., 2016), short-term leverage (Agarwal \& Mohtadi, 2004; Bokpin \& Ishhraq, 2008; Bokpin, 2009; Joeveer, 2013; Muthama et al., 2013; Mokhova \& Zinecker, 2014; Huong, 2017) and long-term leverage (Mahmud, 2003; Agarwal \& Mohtadi, 2004; Gajurel, 2006; Bokpin \& Ishhraq, 2008; Bokpin, 2009; Joeveer, 2013; Muthama et al., 2013; Mokhova \& Zinecker, 2014; Vo, 2017; Huong, 2017; Alqatamin, 2018). Some also suggest largely robustness of outcomes under different indicators (Salam \& Shourkashti, 2019). This study applies a common measurement of overall leverage using the debt ratio, i.e. total debt divided by total assets. Following many 
previous studies, we use return on assets as the measurement of profitability (Bokpin, 2009; Baharuddin et al., 2011; Nejad \& Wasiuzzaman, 2015; Temimi, 2016; Pepur et al., 2016; Ying et al., 2016; Huong, 2017; Vo, 2017; Alqatamin, 2018). Logarithm of total assets or sales is commonly used to proxy firm size (Joeveer, 2013; Nejad, 2015; Bandyopadhyay \& Barua, 2016; Temimi et al., 2016; Ying et al., 2016; Huong, 2017; Vo, 2017; Khemiri \& Noubbigh, 2018). For this study, we opt for the natural logarithm of total assets. Following Nejad \& Wasiuzzaman (2015), Ying et al. (2016), Pepur et al. (2016), and Khemiri \& Noubbigh (2018), NDTS is measured using a ratio of depreciation and amortisation to total assets. The tangibility is represented by net fixed assets to total assets (Nejad \& Wasiuzzaman, 2015; Pepur et al., 2016; Temimi, 2016; Bandyopadhyay \& Barua, 2016; Huong, 2017; Vo, 2017; Khemiri \& Noubbigh, 2018). The net fixed assets include only the book value of property, plant, equipment. Generally, firms with high liquidity tend to have better ability to fulfil short-term obligations. The financial liquidity of firm is measured by the current ratio, i.e. current assets divided by current liabilities (Bandyopadhyay \& Barua, 2016; Pepur et al., 2016; Temimi, 2016; Ying, 2016; Huong, 2017; Vo, 2017). GDP growth represents the economic growth of a country. We apply annual real GDP growth rate as being commonly seen in the literature (Muthama et al., 2013; Mokhova \& Zinecker, 2014; Tomschik, 2015; Rehman, 2016; Temimi, 2016; Huong, 2017). To measure inflation, some studies refer to the consumer price index (CPI) (Khemiri \& Noubbigh, 2018), some use the GDP deflator (Mokhova \& Zinecker, 2014; Pepur et al., 2016; Rehman, 2016) and some use the annual percentages in CPI (Gajurel, 2006; Bokpin, 2009; Muthama et al., 2013; Nejad \& Wasiuzzaman, 2015; Temimi et al., 2016; Ying et al., 2016; Huong, 2017). Generally, low interest rate encourages firms to increase debt due to lower cost of debt. The market-wide interest rate reference can be based on the lending rate (Mahmud, 2003; Nejad \& Wasiuzzaman, 2015; Huong, 2017), real interest rate (Rehman, 2016), short-term or long-term interest rates (Mokhova \& Zinecker, 2014), and treasury-bill rate (Muthama et al., 2013). We refer to lending rate in this study. Whereas for taxation, the effective tax rate measured using corporate income tax expense divided by earnings before tax is tested (Nejad \& Wasiuzzaman, 2015; Rehman, 2016; Huong, 2017). Following the studies such as by Agarwal \& Mohtadi, (2004), Bokpin \& Ishhraq (2008), Temimi (2016), Gajurel (2006), Tai (2017) and Khemiri \& Noubbigh (2018), we use the ratio of stock market capitalisation to GDP to represent stock market development.

Our sample data consists of observations across firms and over time. As such, this study applies panel data regressions in estimating the relationship between the capital structure proxy and the independent variables. The following is the basic equation for the multiple regression model:

$$
L E V_{i t}=\beta_{0}+\beta_{1} N D T S_{i t}+\beta_{2} S_{I Z E_{i t}}+\beta_{3} P_{R O F} i t+\beta_{4} T A N G_{i t}+\beta_{5} L I Q_{i t}+\beta_{6} T A X_{i t}+\varepsilon_{i t}
$$

This model includes all firm specific factors (NDTS, firm size, profitability, assets tangibility, liquidity, and taxation), where LEV $_{i t}$ is total debt ratio, NDTS ${ }_{i t}$ is depreciation to total assets, SIZE $_{i t}$ is firm size, PROF it is profitability, $T A N G_{i t}$ is tangibility, $L I Q_{i t}$ is liquidity, $T A X_{i t}$ is taxation, $\beta_{n}$ is the coefficient of respective explanatory variables, and $\varepsilon_{i t}$ is error term. i denote firms and $t$ denotes time. The same model will be checked against the following model with the inclusion of macroeconomic variables.

$$
\begin{aligned}
& \text { LEV }_{i t}=\beta_{0}+\beta_{1} \text { NDTS }_{i t}+\beta_{2} \text { SIZE }_{i t}+\beta_{3} \text { PROF }_{i t}+\beta_{4} \text { TANG }_{i t}+\beta_{5} \text { LIQ }_{i t}+\beta_{6} \text { TAX }_{i t}+\beta_{7} \text { GDP }_{t}+\beta_{8} I N F_{t}+\beta_{9} I N T_{t}+ \\
& \beta_{10} \text { STOCK }_{t}+\varepsilon_{i t}
\end{aligned}
$$

Where $\mathrm{GDP}_{\mathrm{t}}$ is GDP growth, $I N F_{t}$ is inflation rate, INT $\mathrm{T}_{\mathrm{t}}$ is interest rate, and $\mathrm{STOCK}_{\mathrm{t}}$ is stock market development. The estimations consider the appropriateness of using pooled ordinary least squares (OLS) regression, fixed effects and random effects models in investigating the capital structure determinants. The panel pooled OLS assumes the intercept to be constants across all firms, as assumed in any typical OLS estimation. The consideration of using fixed effects model and random effects model is to deal with potential problems of specific effect or heterogeneity. Fixed effects model and random effects model help to control the time variant and invariant effects. Breusch-Pagan Lagrangian Multiplier (BPLM) is used to test the presence of heterogeneity. The Hausman specification test is implemented to check if the random effects model is more efficient than the fixed effects model. Besides, the possible existence of multicollinearity problem is considered in our analysis. The descriptive statistics of variables for the sample are shown in Table 1 below. 
Table 1. Descriptive Statistics

\begin{tabular}{|c|c|c|c|c|}
\hline Variable & Mean & Standard Deviation & Min & Max \\
\hline LEV & 0.186 & 0.163 & 0.000 & 2.375 \\
\hline NDTS & 0.176 & 11.344 & 0.000 & 881.92 \\
\hline SIZE & 5.545 & 0.715 & 1.415 & 8.186 \\
\hline PROF & 2.765 & 37.179 & -1895.0 & 633.78 \\
\hline TANG & 0.332 & 0.224 & 0.000 & 0.980 \\
\hline LIQ & 3.653 & 8.997 & 0.000 & 312.43 \\
\hline TAX & 0.174 & 3.372 & -151.38 & 105.95 \\
\hline GDP & 4.730 & 2.246 & -1.510 & 7.420 \\
\hline INT & 4.766 & 0.191 & 4.540 & 5.080 \\
\hline MC & 1.382 & 0.142 & 1.123 & 1.603 \\
\hline INF & 2.122 & 0.979 & 0.580 & 3.870 \\
\hline
\end{tabular}

Note: LEV (leverage) is the total debt to total assets ratio. NDTS (non-debt tax shield) is a ratio of depreciation to total assets. SIZE is the natural logarithm of total assets. PROF (profitability) is the ratio of net profit to total assets. TANG (tangibility) is the ratio of total fixed assets to total assets. LIQ (liquidity) is a ratio of current assets to current liabilities. TAX is the ratio of tax expense to earnings before tax. GDP (gross domestic product) growth is the yearly changes in GDP. INT (interest rate) the lending rate. INF (inflation) is the changes in the consumer price index. MC (stock market development) is measured as a ratio of stock market capitalisation to GDP.

\section{Findings and Discussions}

The results report the investigation of determinants of capital structure for a panel of 612 firms listed in the Bursa Malaysia over the period of 2009 to 2018. Table 2 presents the correlation matrix of the variables. We refer to variance inflation factor (VIF) as a widely used method to identify possible multicollinearity problem. Table 3 shows that the VIF values for both the firm-specific and macroeconomic variables are at low readings, suggesting no multicollinearity problem in the estimations of proposed equations.

Table 2. Correlation Matrix

\begin{tabular}{|c|c|c|c|c|c|c|c|c|c|c|c|}
\hline & TDTA & NDTS & SIZE & PROF & TANG & LIQ & TAX & GDP & R & MC & IF \\
\hline TDTA & 1.0000 & & & & & & & & & & \\
\hline NDTS & -0.0152 & 1.0000 & & & & & & & & & \\
\hline SIZE & 0.3419 & -0.0781 & 1.0000 & & & & & & & & \\
\hline PROF & -0.0317 & -0.1026 & 0.1716 & 1.0000 & & & & & & & \\
\hline TANG & 0.1096 & -0.0190 & 0.0913 & -0.0160 & 1.0000 & & & & & & \\
\hline LIQ & -0.2737 & -0.0070 & -0.1029 & 0.0083 & -0.1478 & 1.0000 & & & & & \\
\hline TAX & 0.0054 & -0.0010 & 0.0037 & 0.0073 & -0.0060 & -0.0025 & 1.0000 & & & & \\
\hline GDP & -0.0179 & -0.0031 & 0.0339 & 0.0023 & -0.0032 & 0.0145 & 0.0265 & 1.0000 & & & \\
\hline R & 0.0193 & -0.0156 & -0.0863 & 0.0112 & 0.0383 & -0.0112 & 0.0060 & -0.3656 & 1.0000 & & \\
\hline MC & -0.0055 & -0.0160 & -0.1005 & -0.0004 & -0.0105 & 0.0032 & 0.0101 & 0.1384 & 0.1558 & 1.0000 & \\
\hline IF & -0.0184 & -0.0005 & 0.0399 & -0.0004 & 0.0541 & 0.0044 & -0.0029 & 0.5412 & -0.5830 & 0.0797 & 1.0000 \\
\hline
\end{tabular}

Table 3. VIF test

\begin{tabular}{|c|c|}
\hline Variable & VIF \\
\hline INF & 1.90 \\
\hline INTR & 1.64 \\
\hline GDP & 1.45 \\
\hline MC & 1.11 \\
\hline SIZE & 1.07 \\
\hline PROF & 1.04 \\
\hline TANG & 1.04 \\
\hline LIQ & 1.03 \\
\hline NDTS & 1.02 \\
\hline TAX & 1.00 \\
\hline
\end{tabular}


Comparisons with the estimations using pooled OLS, fixed effects and random effects models are performed for both the Equation (1) and Equation (2) to achieve the purpose of consistency and robustness checks. The Hausman specification test is used to examine the appropriate model to refer between the fixed effects and the random effects. If the Hausman test shows a p-value more than 0.05 , then the difference in coefficients is not systematic and the random effects estimation is more efficient than fixed effects. In our estimation, the Hausman specification test shows that the $p$-value is higher than 0.05 for all both the equations (1) and (2). BPLM is used to compare the appropriateness between the pooled OLS and random effects models. Our BPLM result of less than $0.05 \mathrm{p}$-value indicates that there are significant differences among panels and the random effects should be considered. Nevertheless, the output of all models are reported to present the robustness of our results. Table 4 reports the main results of regression analysis for the random effects model in Malaysia over the period from years 2009 to 2018. The debt ratio is regressed on the firm-specific factors with and without the macro-wide economic factors for comparison purposes.

Table 4. Regression Results of Leverage on Firm-Specific and Macroeconomic Determinants

\begin{tabular}{|c|c|c|}
\hline Variables & Equation (1) & Equation (2) \\
\hline NDTS & 0.000308 & 0.000367 \\
& $(2.67)^{* * *}$ & $(3.19)^{* * *}$ \\
\hline SIZE & 0.078409 & 0.089193 \\
& $(15.66)^{* * *}$ & $(17.10)^{* * *}$ \\
\hline PROF & -0.000433 & -0.000471 \\
& $(-7.35)^{* * *}$ & $(-8.00)^{* * *}$ \\
\hline TANG & 0.101212 & 0.094237 \\
& $(8.93)^{* * *}$ & $(8.30)^{* * *}$ \\
\hline CR & -0.003625 & -0.003559 \\
& $(-13.72)^{* * *}$ & $(-13.53)^{* * *}$ \\
\hline TAX & -0.000434 & -0.000480 \\
& $(-0.82)$ & $(-0.91)$ \\
\hline GDP & - & -0.001199 \\
& & $(-1.80)^{*}$ \\
\hline INF & - & -0.000710 \\
& & $(-0.40)$ \\
\hline R & - & 0.033177 \\
& & $(3.95)^{* * *}$ \\
\hline MC & - & 0.035937 \\
& & $(3.79)^{* * *}$ \\
\hline Intercept & -0.269618 & -0.527968 \\
& $(-9.45)^{* * *}$ & $(-9.62)^{* * *}$ \\
\hline R squared & 0.1689 & 0.1713 \\
\hline
\end{tabular}

Note: Figures in the parentheses are test statistics. $*, * *$ and $* * *$ indicate $10 \%, 5 \%$ and $1 \%$ significance levels respectively.

As can be observed from Table 4, the results from Equation (1) with only the firm-specific determinants are largely consistent with the results from Equation (2) including the macro-economic variables. It mainly supports the argument on the importance of these firm-specific determinants widely proposed in the current literature. These variables are found to be important in the Malaysian market at least for these recent ten years of sample period. The effects of NDTS, size, profitability, tangibility, liquidity and taxation generally indicate consistency in terms of sign (positive/negative) and level of significance when the estimations are performed with and without the inclusion of macro-economic variables. Such findings provide further empirical supports for the roles of firm-level determinants. The NDTS is positively related to total debt for Malaysian firms at one percent significance level. This study supports Khemiri \& Noubigh (2018) who found a significant positive between non-debt tax shields and firm's leverage. It is justifiable to say that NDTS or tax deductibility on depreciation charges is not sufficient to substitute the benefit of tax deductibility with debt. Thus, firms may continue to increase leverage to enjoy the tax benefit 
from interest expenses. Firm size shows a significant positive relationship with leverage, indicating that larger firms typically use a higher amount of debt as they are usually perceived to be in a better position to payback. This result is also consistent with the findings by Baharuddin et al. (2011), Temimi (2016), Ying et al. (2016), Huong (2017), Khemiri \& Noubigh (2018). The positive association indicates that larger companies tend to borrow more as they generally have an easier access to loans due to the higher confidence by creditors. The similar explanation could be found on the assets tangibility. Tangibility has a significant positive relationship with debt financing for the Malaysian firms in our estimations. These tangible assets could serve as collaterals and the lenders are more confident and likely to provide credit facilities backed by tangible assets. Such a finding is consistent the studies by Baharuddin et al. (2011), Joeveer (2013), Nejad \& Wasiuzzaman (2015), Ying et al. (2016) and Huong (2017).

In contrast, the result shows that profitability has a significant negative relationship with debt ratio for the Malaysian firms in both equations. This is in line with the pecking order theory, proposing that firms prefer internal financing for their operations and growth if they have sufficient funds. These firms may avoid leverage due to no necessity to do so (Temimi, 2016; Alqatamin, 2018). Similarly, liquidity indicates a negative relationship with debt ratio for the Malaysian firms in both estimations with and without the controls of macro-economic factors. It implies that if firms possess high liquid assets, then they can make use of these assets in financing their businesses thus excessive external financing may not be necessary. This is also consistent with the implications of pecking order theory and in line with the findings by Pepur et al. (2016) and Huong (2017). However, our estimations fail to find a significant relationship between taxation and leverage for the same sample, suggesting that the effective tax rates may not be the main concern in raising external debt at least during this period. Similar with the NDTS, the coefficients of firm size, profitability, tangibility and liquidity exhibit an association at one percent significance level in both equations.

While the results highlight the robustness of the commonly discussed firm-specific factors, we are also interested in looking into the possible impacts of macro-economic variables over time in the Equation (2). Though significant at only 10 percent level, the GDP indicates a negative effect on debt ratio. This may imply decent firm performance during the time when the GDP growth is high, thus reducing the needs of external debt financing. Such behaviour is also in line with the pecking-order theory. Meanwhile, there is a negative but insignificant relationship between inflation and debt ratio. During these years, the inflation has usually been related to the economic growth. Therefore, a similar observation with the GDP coefficient is sensible. Nevertheless, a positive and significant coefficients of interest rate may imply the effect on real cost of debt (Ying, 2016), while high inflation usually leads to the increases in interest rates (cost of debt), the nominal interest rates may not represent the real cost of debt. The real cost could be lower when the inflation expectation is high due to economic growth. This may encourage firms to borrow in anticipation of better future incomes. For checking purpose, we find that the estimated result is consistent even if we separate the models in which one excludes interest rate while another model drops the inflation rate. For stock market development, there is also a significant positive relationship with leverage at one percent significance level. A more developed stock market indicates a healthy financial development which could lead to easier financing from institutions, partly boosted by the confidence of creditors. Consistent with the findings by Gajurel (2006), Tomschik (2015), Rehman (2016) and Tai (2017), stock market performance has a positive relationship with firm borrowings as good market conditions increase the willingness of lenders to offer funds. While it also suggests an easier access to equity financing, the expansion of equity in book value could still be slower than the increase in debt.

Besides, we would also like to check if the results are robust and consistent across estimations by considering the pooled OLS and the fixed effects models. The results are tabulated for comparisons in Table 5. In summary, it is worth to highlight that the signs and significance of coefficient are largely consistent for most of the proposed variables. The inconsistencies are mainly found in the estimations using pooled OLS. For example, The NDTS does not indicate a significant relationship with leverage when the pooled OLS model is adopted. Though the taxation shows a different sign in the pooled OLS estimations, the same insignificance is found. Nevertheless, all the signs are consistent for the coefficients of macro-economic variables. The only inconsistency in significance level is found in the coefficient of GDP, where the pooled OLS does not suggest a significance level of at least 10 percent. While the results of Hausman specification 
test and BPLM test indicate that the random effects model is more appropriate in explaining our variables, the comparisons across all three models could further support robustness in explaining the capital structure determinants of Malaysian firms. The consistencies help to provide a better ground to propose our findings.

Table 5. Robustness Check with the Estimations using Pooled OLS (POLS) and Fixed Effects (FE) Models

\begin{tabular}{|c|c|c|c|c|c|c|}
\hline & \multicolumn{3}{|c|}{ Equation (1) } & \multicolumn{3}{c|}{ Equation (2) } \\
\hline Variables & POLS & FE & RE & POLS & FE & RE \\
\hline NDTS & 0.000013 & 0.000353 & 0.000308 & 0.000029 & 0.000466 & 0.000367 \\
& $(0.08)$ & $(2.99)^{* * *}$ & $(2.67)^{* * *}$ & $(0.17)$ & $(3.95)^{* * *}$ & $(3.19)^{* * *}$ \\
\hline SIZE & 0.075850 & 0.081886 & 0.078409 & 0.077425 & 0.104597 & 0.089193 \\
& $(26.67)^{* * *}$ & $(11.54)^{* * *}$ & $(15.66)^{* * *}$ & $(26.99)^{* * *}$ & $(13.66)^{* * *}$ & $(17.10)^{* * *}$ \\
\hline PROF & -0.000577 & -0.000429 & -0.000433 & -0.000589 & -0.000496 & -0.000471 \\
& $(-6.97)^{* * *}$ & $(7.09)^{* * *}$ & $(-7.35)^{* * *}$ & $(-7.12)^{* * *}$ & $(-8.17)^{* * *}$ & $(-8.00)^{* * *}$ \\
\hline TANG & 0.032467 & 0.124831 & 0.101212 & 0.030061 & 0.117893 & 0.094237 \\
& $(3.60)^{* * *}$ & $(9.73)^{* * *}$ & $(8.93)^{* * *}$ & $(3.33)^{* * *}$ & $(9.20)^{* * *}$ & $(8.30)^{* * *}$ \\
\hline CR & -0.005783 & -0.003315 & -0.003625 & -0.005765 & -0.003249 & -0.003559 \\
& $(-19.07)^{* * *}$ & $(-12.10)^{* * *}$ & $(-13.72)^{* * *}$ & $(-19.03)^{* * *}$ & $(-11.92)^{* * *}$ & $(-13.53)^{* * *}$ \\
\hline TAX & 0.000299 & -0.000500 & -0.00434 & 0.000264 & -0.000547 & -0.000480 \\
& $(0.38)$ & $(-0.95)$ & $(-0.82)$ & $(0.33)$ & $(-1.04)$ & $(-0.91)$ \\
\hline GDP & - & - & - & -0.001001 & -0.001352 & -0.001199 \\
& & & & $(-0.95)$ & $(-2.04)^{* *}$ & $(-1.80)^{*}$ \\
\hline INF & - & - & - & -0.001060 & -0.000586 & -0.000710 \\
& & & & $(-0.38)$ & $(-0.33)$ & $(-0.40)$ \\
\hline R & - & - & - & 0.027782 & 0.036030 & 0.033177 \\
& & & & $(2.11)^{* *}$ & $(4.27)^{* * *}$ & $(3.95)^{* * *}$ \\
\hline MC & - & - & - & 0.029459 & 0.040694 & 0.035937 \\
& & & & $(2.01)^{* *}$ & $(4.21)^{* * *}$ & $(3.79)^{* * *}$ \\
\hline Intercept & -0.224319 & -0.297091 & -0.269618 & -0.398518 & -0.641473 & -0.527968 \\
& $(-13.95)^{* * *}$ & $(-7.42)^{* * *}$ & $(-9.45)^{* * *}$ & $(-5.91)^{* * *}$ & $(-9.56)^{* * *}$ & $(-9.62)^{* * *}$ \\
\hline R squared & 0.1836 & 0.1617 & 0.1689 & 0.1862 & 0.1640 & 0.1713 \\
\hline
\end{tabular}

Note: Figures in the parentheses are test statistics. ${ }^{*},{ }^{* *}$ and ${ }^{* * *}$ indicate $10 \%, 5 \%$ and $1 \%$ significance levels respectively.

The overall results suggest that the explanatory variables are relevant and significant in determining the capital structure of firms in Malaysia. It is worth to note that the comparisons between Equation (1) and Equation (2) propose that the firm-specific determinants remain very important even after the inclusion of macro-economic variables, which have also been tested to be significant in this study. This finding is robust across the three panel regression models. Besides, the results are largely consistent with the predictions and implications of the trade-off theory and pecking order theory. In the Malaysian market, NDTS, firm size, tangibility, interest rate and stock market development are positively significant related to leverage whereas the profitability and liquidity are negatively significant related to leverage. Tax and inflation rate are insignificantly related to capital structure in our sample. This study aims to contribute to the literature towards a better understanding of capital structure determinants in Malaysia.

\section{Conclusions}

In conclusion, the findings from panel regressions are largely consistent with the modern theories and existing studies. This study contributes to the literature by further highlighting the significance of firmspecific factors considering the controls of macroeconomic conditions. The results reveal that in Malaysia, NDTS, firm size, tangibility, profitability, liquidity, GDP, interest rate and market capitalisation exhibit significant relationships with capital structure decisions. This study can be of interest for different groups of decision makers. Creditors are interested in understanding about capital structure to be more cautious in choosing which firms to finance or offer loans. Shareholders are interested in understanding how firms determine their capital structure based on the factors examined. Finance managers are interested in looking for proper bases to plan about their firm's financing activities. The results of this study also imply 
that managers and investors should not only look into the firm-specific factors, but also consider the macro-economic conditions when making investment decisions. For instance, high GDP growth suggests that the country's production is high and so its demand. Firms could produce more to take advantage of such increasing demand and growth opportunities. In return, profitability could improve and the firm may not need external funds to finance their operations and growth. Last but not least, this study could also contribute to the existing literature by serving as an empirical reference for future research about macroeconomic factors on firm-level capital structure decisions. The future research may consider investigating a larger sample in terms of firms and countries, given various economic conditions across different countries. Our observations for the Malaysian firms may not be applicable for some other markets. In addition, studies about regional behaviour like the ASEAN or Asia-Pacific markets can also be deemed sensible. Further explorations of the other variables, for example but not limited to exchange rates, bond market development, stock market performance, financial and trade openness, which may fundamentally explain the capital structure decisions are also recommended to help in better understanding firms' financing behaviour.

\section{References}

1. Agarwal, S., \& Mohtadi, H. (2004). Financial markets and the financing choice of firms: Evidence from developing countries. Global Finance Journal, 15(1), 57-70.

2. Alqatamin, R. M. (2018). Capital structure and CEO's personal characteristics: Evidence from Jordan. International Journal of Academic Research in Accounting, Finance and Management Sciences, 8(2), 113-125.

3. Baharuddin, N. S., Khamis, Z., Mahmood, W. M., \& Dollah, H. (2011). Determinants of capital structure for listed construction companies in Malaysia. Journal of Applied Finance \& Banking, 1(2), 115132.

4. Bandyopadhyay, A., \& Barua, N. M. (2016). Factors determining capital structure and corporate performance in India: Studying the business cycle effects. The Quarterly Review of Economics and Finance, $61,160-172$.

5. Battacharjee, A., \& Dash, M. (2015). Determinants of capital structure in the Indian sugar sector. Sky Journal of Business Administration and Management, 3(6), 63-69.

6. Bokpin, G. A., \& Isshaq, Z. (2008). Stock market development and financing decisions of listed firms in Ghana. African Journal of Business Management, 2, 209-216.

7. Bokpin, G. A. (2009). Macroeconomic development and capital structure decisions of firms. Studies in Economics and Finance, 26(2), 129-142.

8. Daskalakis, N., Balios, D., \& Dalla, V. (2017). The behaviour of SMEs capital structure determinants in different macroeconomic states. Journal of Corporate Finance, 46, 248-260.

9. Gajurel, D. P. (2006). Macroeconomic Influences on Corporate Capital Structure. SSRN Electronic Journal, 0-9. Available at https://doi.org/10.2139/ssrn.899049.

10. Huong, P. T. Q. (2017). Macroeconomic factors and corporate capital structure: Evidence from listed joint stock companies in Vietnam. International Journal of Financial Research, 9(1), 31

11. Jensen, M. C., \& Meckling, W. H. (1976). Theory of the firm: Managerial behavior, agency costs and ownership structure. Journal of Financial Economics, 3(4), 305-360.

12. Jõeveer, K. (2013). Firm, country and macroeconomic determinants of capital structure: Evidence from transition economies. Journal of Comparative Economics, 41(1), 294-308.

13. Khémiri, W., \& Noubbigh, H. (2018). Determinants of capital structure: Evidence from subSaharan African firms. The Quarterly Review of Economics and Finance, 70, 150-159.

14. Kiraci, K., \& Aydin, N. (2018). Determinants of capital structure: Empirical evidence from traditional airlines. International Journal of Economic and Administrative Studies, 21, 173-186.

15. Kraus, A., \& Litzenberger, R. H. (1973). A state-preference model of optimal financial leverage. Journal of Finance, 28(4), 911-922.

16. Mahmud, M. (2003). The relationship between economic growth and capital structure of listed companies: Evidence of Japan, Malaysia, and Pakistan. The Pakistan Development Review, 42(4II), 727-750. 
17. Memon, P. A., Rus, R. B. M., \& Ghazali, Z. B. (2015). Firm and macroeconomic determinants of debt: Pakistan evidence. Procedia - Social and Behavioral Sciences, 172, 200-207.

18. Mokhova, N., \& Zinecker, M. (2014). Macroeconomic factors and corporate capital structure. Procedia - Social and Behavioral Sciences, 110, 530-540.

19. Muthama, C., Mbaluka, P., \& Kalunda, E. (2013). An empirical analysis of macro-economic influences on corporate capital structure of listed companies in Kenya. Journal of Finance and Investment Analysis, 2(2), 41-62.

20. Nejad, N. R., \& Wasiuzzaman, S. (2015). Multilevel determinants of capital structure: Evidence from Malaysia. Global Business Review, 16(2), 199-212.

21. Pepur, S., Ćurak, M., \& Poposki, K. (2016). Corporate capital structure: The case of large Croatian companies. Economic Research-Ekonomska Istraživanja, 29(1), 498-514.

22. Ramli, N. A., Latan, H., \& Solovida, G. T. (2019). Determinants of capital structure and firm financial performance-A PLS-SEM approach: Evidence from Malaysia and Indonesia. The Quarterly Review of Economics and Finance, 71, 148-160.

23. Rehman, Z. U. (2016). Impact of macroeconomic variables on capital structure choice: A case of textile industry of Pakistan. The Pakistan Development Review, 55(3), 227-239.

24. Salam, Z. A., \& Shourkashti, R. (2019). Capital structure and firm performance in emerging market: An empirical analysis of Malaysian companies. International Journal of Academic Research in Accounting, Finance and Management Sciences, 9(3), 70-82.

25. Tai, L. M. (2017). Impact of the financial markets development on capital structure of firms listed on Ho Chi Minh Stock Exchange. International Journal of Economics and Financial Issues, 7(3), 510-515.

26. Tehrani, R., \& Khoee, S. N. (2017). The effect of inflation uncertainty on the capital structure of non-financial firms. Palma Journal, 16(3), 523-530.

27. Temimi, A., Zeitun, R., \& Mimouni, K. (2016). How does the tax status of a country impact capital structure? Evidence from the GCC region. Journal of Multinational Financial Management, 37-38, 71-89.

28. Tomschik, D. (2015). The impact of macroeconomic variables on capital structure: A comparison between companies in E7 and G7 countries. University of Twente Student Theses. Available at https://essay.utwente.nl/67363/.

29. Vo, X. V. (2017). Determinants of capital structure in emerging markets: Evidence from Vietnam. Research in International Business and Finance, 40, 105-113.

30. Ying, Y., Albaity, M., \& Zainir, F. (2016). Determinants of capital structure: A comparison between industrial and consumer sectors in China. Asian Journal of Business and Accounting, 9(2), 1-39. 